\title{
Population Fluctuation of Selenaspidus articulatus Morgan (Hemiptera: Diaspididae) in Rubber Tree
}

\author{
Jéssica Ferreira Silva ${ }^{1}$ (D) 0000-0001-8984-5621 \\ Jaqueline Magalhães Pereira ${ }^{1}$ (D) 0000-0002-4911-555X \\ Daniel Floriano das Chagas ${ }^{1}$ (1) 0000-0002-4194-7212 \\ Vitor Pureza Cardoso ${ }^{1}$ (1) 0000-0002-6539-8772 \\ Ohana Daroszewski Rodrigues ${ }^{1}$ (1) 0000-0002-7860-0191
}

\begin{abstract}
Rubber tree is the main source of natural rubber in the world. Because of its economic importance, cultivation was accentuated in several regions of Brazil in the form of monoculture, thus favoring insects to establish in the crop. Among them, the West Indian red scale cochineal Selenaspidus articulatus stands out, responsible for injuring rubber plants due to sap sucking. This work evaluated the fluctuation of S. articulatus in rubber tree clones. Sampling was carried out by collecting leaves every 15 days from PB 235, RRIM 600, PR 255 and GT 1 clones during the period of March 2013 and March 2014. RRIM 600 clone showed the highest population level of S. articulatus, with a population peak of 14.88 insects/leaf in June. PR 255 clone had the lowest scale infestation, demonstrating this clone's possible resistance to this species. This is the first report of $S$. articulatus occurrence in Goiás.
\end{abstract}

Keywords: West Indian red scale, Hevea brasiliensis, seasonality.

\section{INTRODUCTION AND OBJECTIVES}

The rubber tree Hevea brasiliensis Müell. Arg. (Euphorbiaceae) is a native species to the Amazon region and stands out as being the main source of natural rubber in the world (Coelho et al., 2009; Gonçalves et al., 2002). This plant is associated with a pest complex, especially mites (Ferla \& Moraes, 2008), leaf-cutting ants of the Atta and Acromyrmex genus (Anjos et al., 2008) and the lace bug Leptopharsa heveae Drake \& Poor (Santos \& Freitas, 2008). In addition to these, there are reports of other associated insects, among them termites, chrysomelids, whiteflies, cochineals, mole crickets, wood boring beetles and caterpillars (Santos \& Pereira, 2008).

The first report of high Selenaspidus articulatus cochineal populations in rubber trees occurred in 1988 in the municipality of Olímpia, São Paulo state (Bergmann et al., 1988). Belonging to the group of scaled cochineals, they cause damage to perennial and ornamental plants (Culik et al., 2008) and are considered important pests (Henderson, 2011). The main damage is caused by continuous sap sucking from leaves, fruits and branches. However, these insects can introduce toxins that cause leaf fall and influence fruit quality (Bartra, 1974). The genera Pinnaspis, Aspidiotus and Saissetia are found in the rubber tree culture (Bergmann et al., 1988; Bergmann et al., 1991). Santos \& Pereira (2008) report some species associated with rubber tree, such as Pinnaspis sp., Aspidiotus destructor Signoret, Saissetia coffeae Walker, Sa. oleae Oliv., Parasaissetia nigra Nietner, Asterolecanium pustulans Cockerell and Hemiberlesia lataniae Signoret.

West Indian red scale $S$. articulatus has been reported in Brazil in several species of host plants in the tropical and subtropical regions, namely cherimoya (Annona cherimola), coconut palm (Cocos nucifera), passion fruit (Passiflora edulis), mango (Mangifera indica), banana (Musa spp.), soursop (Annona muricata), avocado (Persea americana), black pepper (Piper nigrum) and palm trees (Bartra, 1974). However, this species is associated with other host species, among them Citrus limon (Hodgson \& Lagowska, 2011), Citrus reticulata (Rodrigues et al., 2009), Citrus latifolia (Vargas et al., 2015), Coffea spp., Ficus sp., Gardenia sp., Pandanus sp. (García et al., 2016),

\footnotetext{
${ }^{1}$ Universidade Federal de Goiás (UFG), Goiânia, GO, Brasil
} 
rubber tree (Bergmann et al., 1988) and Mimosa caesalpiniaefolia (Ferraz, 1997).

In recent years, an increase in the $S$. articulatus population in escape areas of the rubber tree has been observed. In some areas, the $S$. articulatus population is higher than L. heveae. However, no studies on this species have been carried out on rubber tree since the first report. It is necessary to verify the seasonality of this insect in several environments to contribute to integrated pest management in rubber tree plantation. In addition, it is necessary to observe if the rubber tree clones influence the population of this species. Thus, the objective of this study was to evaluate the population of West Indian red scale cochineals in rubber tree clones.

\section{MATERIALS AND METHODS}

The study was carried out in the commercial areas of OL Látex Ltda. $\left(15^{\circ} 19^{\prime} 21^{\prime \prime} \mathrm{S}\right.$ and $\left.49^{\circ} 9^{\prime} 32^{\prime \prime} \mathrm{W}\right)$ (Figure 1) in the municipality of Goianésia, Goiás, Brazil. The climate of the region is Aw, tropical climate with dry winter season, according to the Koppen classification, with a well-defined rainy summer season and dry winter.

Sampling was performed in areas of PB 235, RRIM 600, PR 255 and GT 1 clones. The evaluations occurred every 15 days, quantifying the amount of $S$. articulatus during the period of March 2013 and March 2014, totalizing 26 evaluations.

At each sampling, 15 trees/clones were randomly selected, and three leaves/plants were collected at a height of $7 \mathrm{~m}$ using pruning shears with a telescopic handle. After the collection, the leaves were packed in plastic bags and transported in an isothermal polystyrene box refrigerated with gel packs. The samples were kept in the laboratory under refrigeration at $10^{\circ} \mathrm{C}$ for not more than one week until evaluation which was done using a stereoscopic microscope to observe and count the number of nymphs and adults of $S$. articulatus on the leaves (Figure 2).

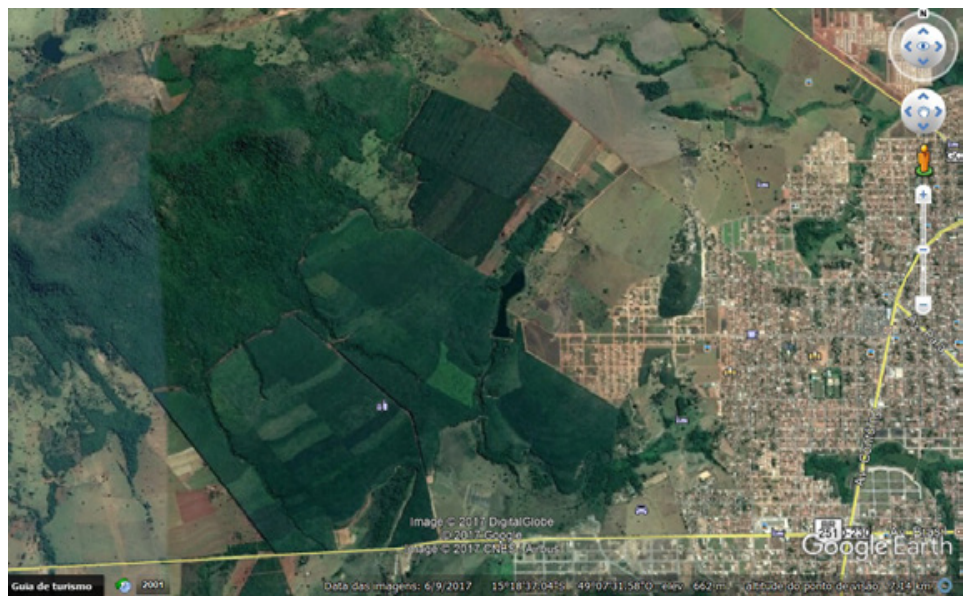

Figure 1. Covoá farm rubber tree area. Goianésia, Goiás, Brazil.

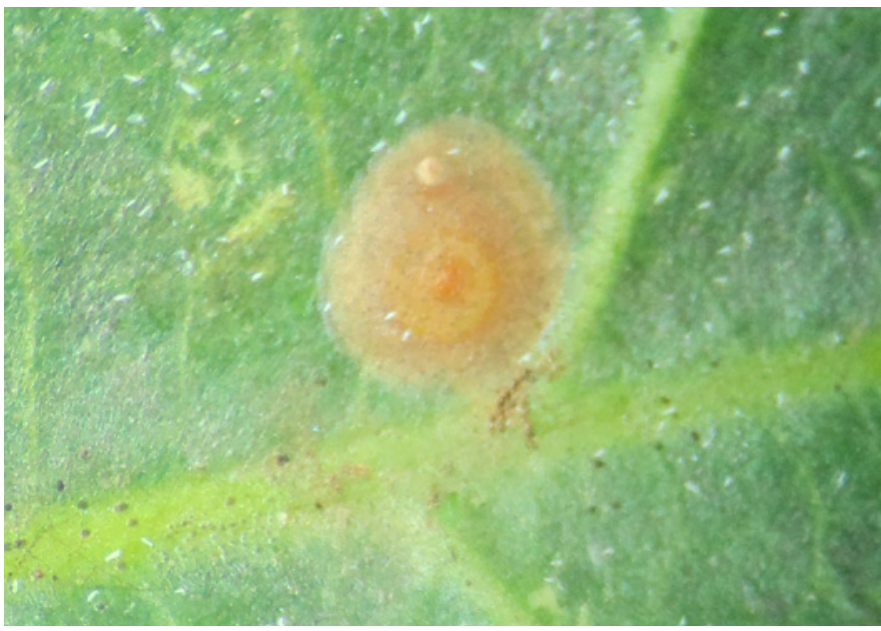

Figure 2. Selenaspidus articulatus in a rubber tree leaf. 
The relation between population density (mean of adults and nymphs/leaf) and meteorological data (maximum, minimum and mean temperature $\left({ }^{\circ} \mathrm{C}\right)$, relative humidity $(\%)$, and precipitation $(\mathrm{mm})$ ) was assessed by linear correlation. The climatic data used were obtained from the Usina Jalles Machado S.A. meteorological station (Figure 3), located in the municipality of Goianésia, Goiás, Brazil $\left(15^{\circ} 12^{\prime} 43^{\prime \prime} \mathrm{S}\right.$ and $48^{\circ} 59^{\prime} 13^{\prime \prime}$ W) $22 \mathrm{~km}$ from the study area.

The data obtained from the insect population during the study period are presented in the population fluctuation plot generated by the R program. The comparison between the clones was performed using the $95 \%$ confidence interval, considering that the population peak occurred between March and July. The population was compared by checking the overlap of the error bars.

\section{RESULTS AND DISCUSSION}

Selenaspidus articulatus was observed in greater abundance from March to July, before the natural senescence period of the leaves (Figure 4). After this period, the insect population reduced drastically; however, from December to January a gradual increase in the population was observed, limited by a decrease in February, followed by a new increase in March. The longest occurrence period of S. articulatus was observed in GT 1 and RRIM 600 clones, whose infestation occurred during four months from April to the second fortnight of July, and from March to June, respectively.

The natural senescence of the clones occurred in July and August. With leaf resprouting, West Indian red scale populations were higher in the months preceding natural senescence, after the end of the rainy season. This population peak coincides with the population increase in the $C$. heveae mite, which mainly occurs from March (Demite \& Feres, 2005; Hernandes \& Feres, 2006; Martins et al., 2012; Vis et al., 2006). The development, reproduction and survival of $C$. heveae are favored in rubber tree between January and April (Daud et al., 2012). Therefore, it can be observed that plant phenology is a factor that contributes to the West Indian red scale population increase. According to Santos et al. (2012), the rubber tree reaches its maximum level of foliage in October, with an increase of soluble nitrogen also occurring due to a rise of precipitation which may favor the population peak of $L$. heveae.

The increase in the population of this species in $\mathrm{PB} 235$ clone began at the end of April and the population peak occurred at the beginning of July. After leaf senescence in the dry period of the year, the West Indian red scale cochineal population was observed in a reduced number in all studied clones, rising again in March 2014. The second population peak of the species occurred in March in PB 235, GT 1 and PR 255 clones. In the following year, the population only remained low in the RRIM 600 clone.

The RRIM 600 clone presented the highest population level of the West Indian red scale cochineal of 14.88 individuals/leaf, followed by the GT 1 clone with a population peak of 10.26 at the end of June. At the beginning of July, the PB 235 clone had a population of eight insects/leaf. However, at the end of the same month, there was a decrease in the insect population due to natural senescence. Bergmann et al. (1988) observed a high S. articulatus population in March and April in the RRIM 600 clone in the state of São Paulo. The population in this study was mainly observed from April to June 2013, with a population peak in April.

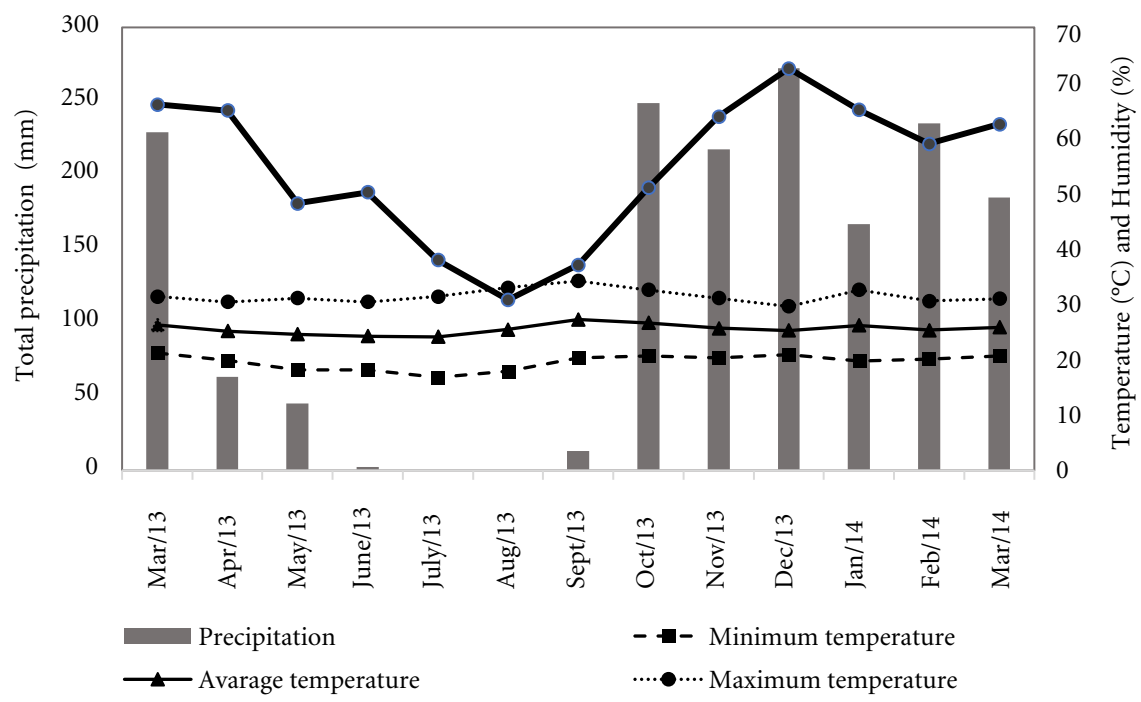

Figure 3. Climatic data (precipitation, average temperature, minimum temperature, maximum temperature and relative humidity) in the periods of 2013-2014 of Usina Jalles Machado meteorological station, Goianésia, Goiás, Brazil. 


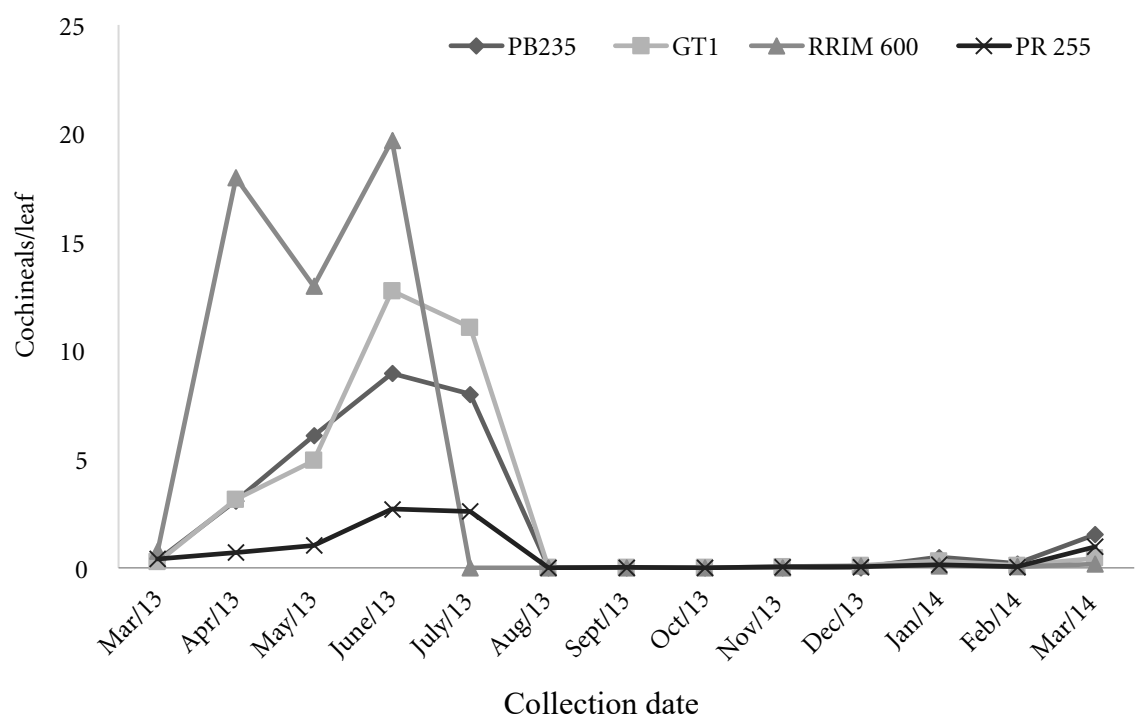

Figure 4. Selenaspidus articulatus population fluctuation in rubber tree clones. Goianésia, Goiás, Brazil.

PR 255 clone presented the lowest cochineal infestation throughout the study. The population began to increase in late May, and the peak population occurred in June (1.7 insects/leaf). The population was three times smaller than the other clones. The cochineal population varied among the evaluated rubber tree clones (Figure 5). PR 255 clone stood out with the lowest population, in contrast to PB 235, GT 1 and RRIM 600 clones. The smallest population in PR 255 is possibly related to the resistance of this clone to S. articulatus.
This result may be indicative of resistance, as Vieira et al. (2009) observed that the FRP/12110 progeny was less attacked by mites (Calacarus heveae and Tenuipalpus heveae), presenting to non-preference or antibiosis resistance. In studies carried out by Ferla \& Moraes (2008), it was possible to observe that PB 260 and PR 255 clones presented larger C. heveae populations and leaf damage. Therefore, rubber tree clones influence the population of mites.

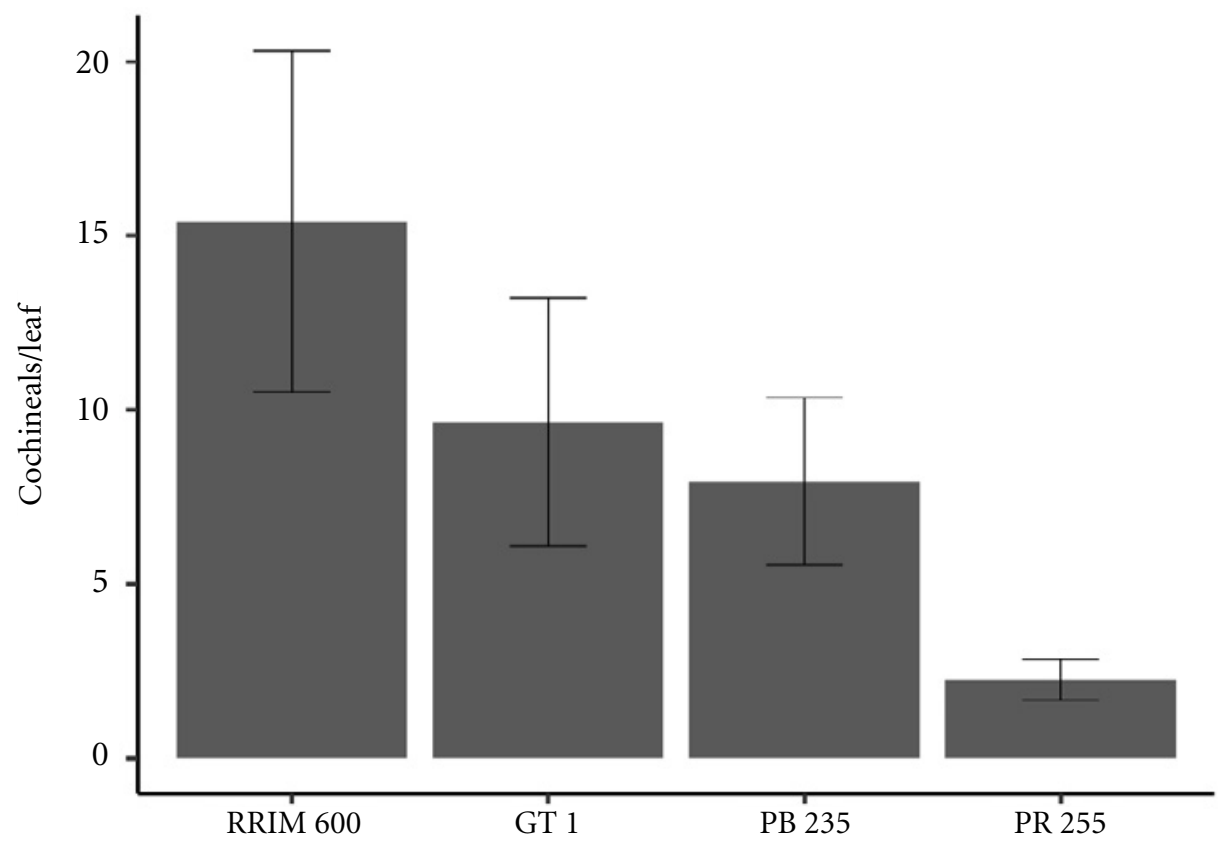

Figure 5. Selenaspidus articulatus ( $\pm 95 \%$ confidence interval) population in rubber tree clones. Goianésia, Goiás, Brazil. 
This difference between the West Indian red scale populations may be correlated to the clones' resistance. However, other factors may influence this population, such as latex production, clone adaptations to soil and climate conditions (Daud et al., 2012). Daud et al. (2013) observed that rubber tree clones may influence the populations of mites. The authors observed that the PB 260 clone presented a smaller population of phytophagous species, whereas the GT 1 clone had the largest population of predators.

The different insect population densities throughout the year are directly related to the climatic conditions, the characteristics of the studied region, and possibly due to the presence of natural enemies that can act in naturally controlling this species. Coccinellids, such as Pentilia egena Mulsant, Coccidophilus citricola Brèthes, Azya luteipes Mulsant, Cycloneda sanguinea L. and Scymnus spp., are important natural enemies of $S$. articulatus in citrus (Rodrigues et al., 2008).

In addition to predatory insects, entomopathogenic fungi stand out, influencing the insect population mainly during periods of high temperature and humidity (Santos \& Pereira, 2008). Long periods of drought may contribute to increasing the insect population due to the lack of favorable conditions for these pathogens to develop.

Perruso \& Cassino (1993) observed lower S. articulatus infestation in Citrus sinensis L. between March and July when temperature and precipitation presented low rates. However, it was possible to observe that the difference in the results in the present study mainly occurs due to phenology and the leaf age in the rubber tree. Moreover, a decrease in the cochineal population in the rubber tree was observed during the rainy season.

No significant correlations were observed between S. articulatus infestation in clones and climatic data. In this case, the physiological conditions of the plant may have influenced the West Indian red scale cochineal population. According to Souza et al. (2015), temperature is the factor that most affects the population size of S. oleae. However, this climatic factor apparently did not influence the West Indian red scale cochineal population in rubber tree.

According to Bergmann et al. (1988), S. articulatus has higher importance in citrus cultivation, and high populations of this insect in rubber trees are related to their proximity to citrus areas. However, the site of this study only has pasture and native vegetation neighboring the rubber tree. Thus, it is believed that the population of this insect is not correlated with citriculture.

West Indian red scale is a cosmopolitan species of African origin (Miller et al., 2005), but it is the only species of Selenaspidus genus that came to be neotropical (Ben-Dov, 2013). The high incidence of this and other insect species represents a potential challenge for tropical forestry and conservation (Normark et al., 2014). S. articulatus was introduced in Brazil and is present in the states of Amazonas, Rio Grande do Norte, Espírito Santo, Minas Gerais, Rio de Janeiro, São Paulo and Rio Grande do Sul (García et al., 2016; Martins et al., 2004). In this way, this is the first report of S. articulatus in the state of Goiás.

\section{Conclusions}

Population peaks of $S$. articulatus occurred before the natural senescence period of the rubber tree. PR 255 clone presents the smallest $S$. articulatus population. This is the first report of S. articulatus occurrence in Goiás state.

\section{Acknowledgements}

We thank OL Látex Ltda. for allowing us performing our work in its property and for the technical support for field samples. We also thank Ana Lucia Benfatti Gonzalez Peronti for identifying the cochineal.

\section{Submission status}

Received: 3 July 2017

Accepted: 8 Aug. 2018

Associate editor: Natália Corniani (1) 0000-0001-7342-5171

\section{Correspondence to}

\section{Jaqueline Magalhães Pereira}

Universidade Federal de Goiás (UFG), Av. Esperança, s/n, CEP 74690-900, Goiânia, GO, Brasil

e-mail: jmpereira@ufg.br

\section{Financial support}

This paper was financed by Fundação de Amparo à Pesquisa do Estado de Goiás (FAPEG), rescript n. 05/2012.

\section{References}

Anjos N, Arnhold A, Corrêa GVV, Stumpf K. Árvores e formigas cortadeiras (Hymenoptera: Formicidae) em Viçosa, Minas Gerais. Revista Trópica: Ciências Agrárias e Biológicas 2008; 2(1): 11-16.

Bartra PCE. Biologia de Selenaspidus articulatus Morgan y sus principales controladores biológicos. Revista Peruana de Entomología 1974; 17(1): 60-68.

Ben-Dov Y. ScaleNet catalogue for Selenaspidus [Internet]. 2013 [cited 2019 Aug. 16]. Available from: https://bit.ly/2OXMQWZ

Bergmann EC, Imenes SDL, Tavares MT. Occurrence of the scale insect Aspidiotus sp. (Hemiptera: Diaspididae) and its parasitoids on ciones of rubber plants in Sao Paulo state. Arquivos do Instituto Biológico 1991; 58(1-2): 65-67. 
Bergmann EC, Stradioto MF, Brisolla AD. Ocorrência de Selenaspidus articulatus (Morgan, 1889) em cultura de seringueira (Hevea brasiliensis Muell. Arg.) no município de Olímpia, estado de São Paulo. O Biológico 1988; 54(1-6): 27-28.

Coelho LM Jr, Rezende JLP, Borges LAC, Oliveira AD. Análise temporal da borracha natural brasileira. Cerne 2009; 15(1): 19-26.

Culik MP, Martins DS, Ventura JA, Wolff VS. Diaspididae (Hemiptera: Coccoidea) of Espírito Santo, Brazil. Journal of Insect Science 2008; 8(1): 1-6. 10.1673/031.008.1701

Daud RD, Feres RJF. Community structure of mites (Arachnida: Acari) in six rubber tree clones. International Journal of Acarology 2013; 39(8): 589-596. 10.1080/01647954.2013.856470

Daud RD, Feres RJF, Hernandes FA. Seasonal suitability of three rubber tree clones to Calacarus heveae (Acari, Eriophyidae). Experimental and Applied Acarology 2012; 56(1): 57-68. 10.1007/ s10493-011-9494-9

Demite PR, Feres RJ. Influência de vegetação vizinha na distribuição de ácaros em seringal (Hevea brasiliensis Muell. Arg., Euphorbiaceae) em São José do Rio Preto, SP. Neotropical Entomology 2005; 34(5): 829-836. 10.1590/S1519-566X2005000500016

Ferla NJ, Moraes GJ. Flutuação populacional e sintomas de dano por ácaros (Acari) em seringueira no estado do Mato Grosso, Brasil. Revista Árvore 2008; 32(2): 365-376. 10.1590/S010067622008000200019

Ferraz LF. Infestação de cochonilha-pardinha em sansão-do-campo usado como cerca viva em pomares de laranja. Bragantia 1997; 56(2): 289-290. 10.1590/S0006-87051997000200008

García MM, Denno BD, Miller DR, Miller GL, Ben-Dov Y, Hardy NB. ScaleNet: a literature-based model of scale insect biology and systematics. Oxford: Database; 2016. 10.1093/database/bav118

Gonçalves PS, Martins ALM, Furtado EL, Sambugaro R, Ottati EL, Ortolani AA et al. Desempenho de clones de seringueira da série IAC 300 na região do planalto de São Paulo. Pesquisa Agropecuária Brasileira 2002; 37(2): 131-138. 10.1590/S0100-204X2002000200003

Henderson RC. Diaspididae (Insecta: Hemiptera: Coccoidea). Lincoln: Manaaki Whenus Press; 2011. (Fauna of New Zealand, n. 66).

Hernandes FA, Feres RJ. Diversidade e sazonalidade de ácaros (Acari) em seringal (Hevea brasiliensis Muell. Arg.) no noroeste do estado de São Paulo. Neotropical Entomology 2006; 35(4): 523-535. 10.1590/S1519-566X2006000400016

Hodgson CJ, Lagowska B. New scale insect (Hemiptera: Sternorrhyncha: Coccoidea) records from Fiji: three new species, records of several new invasive species and an updated checklist of Coccoidea. Zootaxa 2011; 2766(1): 1-29. 10.11646/zootaxa.2766.1.1

Martins DS, Culik MP, Wolff VRS. New record of scale insects (Hemiptera: Coccoidea) as pests of papaya in Brazil. Neotropical Entomology 2004; 33(5): 655-657. 10.1590/S1519566X2004000500018

Martins GLM, Vieira MR, Barbosa JC, Dini TA, Manzano AM, Alves BMS et al. Distribuição espacial de Calacarus heveae Feres na cultura da seringueira em Marinópolis-São Paulo. Revista Árvore 2012; 36(2): 211-217. 10.1590/S0100-67622012000200002

Miller DR, Miller GL, Hodges GS, Davidson JA. Introduced scale insects (Hemiptera: Coccoidea) of the United States and their impact on U.S. agriculture. Proceedings of the Entomological Society of Washington 2005; 107: 123-158.

Normark BB, Morse GE, Krewinski A, Okusu A. Armored scale insects (Hemiptera: Diaspididae) of San Lorenzo National Park, Panama, with descriptions of two new species. Annals of the Entomological Society of America 2014; 107(1): 37-49. 10.1603/ AN13110

Perruso JC, Cassino PCR. Flutuação populacional de Selenaspidus articulatus (Morgan) (Hemiptera: Diaspididae) em Citrus sinensis (L.) no estado do Rio de Janeiro. Anais da Sociedade Entomológica do Brasil 1993; 22: 401-404.

Rodrigues WC, Cassino PCR, Silva Filho R. Ocorrência e distribuição de coccinelídeos (Coleoptera, Coccinellidae) associados às plantas cítricas no estado do Rio de Janeiro. EntomoBrasilis 2008; 1(2): 23-27.

Rodrigues WC, Cassino PCR, Spolidoro MV, Silva Filho R. Insetos sugadores (Sternorrhyncha) em cultivo orgânico de tangerina cv. poncã (Citrus reticulata Blanco): diversidade, constância, freqüência e flutuação populacional. EntomoBrasilis 2009; 2(2): 42-48.

Santos GP, Pereira JMM. Insetos e ácaros associados à cultura da seringueira. In: Alvarenga AP, Carmo CAFS. Seringueira. Viçosa: EPAMIG; 2008. p. 535-597.

Santos RS, Costa VA, Silva JM, Freitas S. Population dynamics of Leptopharsa heveae (Hemiptera: Tingidae) and Erythmelus tingitiphagus (Hymenoptera: Mymaridae) in rubber tree plants. Revista Colombiana de Entomología 2012; 38(2): 214-319.

Santos RS, Freitas S. Erythmelus tingitiphagus (Hymenoptera: Mymaridae): um agente promissor no controle biológico do percevejo-de-renda (Hemiptera: Tingidae) da seringueira. Agrotrópica 2008; 20: 25-28.

Souza GCD, Redaelli LR, Wolff VRDS. Population dynamics of Saissetia oleae (Hemiptera: Coccidae) on olive trees. Revista Brasileira de Fruticultura 2015; 37(4): 852-858. 10.1590/01002945-213/14

Vargas AS, Duarte MN, Santos MRG, Moura LC, Cassino PCR. Dinâmica populacional de insetos-praga em um cultivo agroecológico de lima ácida Tahiti (Citrus latifolia Tanaka) no município de Vassouras-RJ. Revista Eletrônica Teccen 2015; 8(2): 81-84. 10.21727/teccen.v8i2.519

Vieira MR, Silva HAS, Cardoso MM, Figueira JC. Progênies de seringueira com potencial para conferir resistência a ácaros (Calacarus heveae Feres e Tenuipalpus heveae Baker). Ciência Rural 2009; 39(7): 1953-1959. 10.1590/S0103-84782009005000164

Vis RM, Moraes GJD, Bellini MR. Mites (Acari) of rubber trees (Hevea brasiliensis Muell. Arg., Euphorbiaceae) in Piracicaba, state of São Paulo, Brazil. Neotropical Entomology 2006; 35(1): 112-120. 10.1590/S1519-566X2006000100015 